Sains Malaysiana 50(2)(2021): 351-360

http://dx.doi.org/10.17576/jsm-2021-5002-07

\title{
Soil Factors are the Drivers for Wetlands Colonization by Pneumatopteris afra in Nigeria
}

\author{
(Faktor Tanah adalah Pemacu Penjajahan Tanah Lembap oleh Pneumatopteris afra di Nigeria)
}

\author{
AKomolafe GBenga Festus* \& RAHMAd ZaKaRia
}

\begin{abstract}
The relationships between soil factors and plant community characteristics of some wetlands invaded by Pneumatopteris afra and non-invaded ones were investigated. Sixty soil samples were obtained from six wetlands comprising three invaded and three non-invaded in Lafia, Nigeria using sixty quadrants arranged on six $200 \mathrm{~m}$ transects. The samples, after air-dried and sieved using $2 \mathrm{~mm}$ mesh were analysed for the physico-chemical properties which include $\mathrm{pH}$, organic matter (OM), percentage nitrogen (\% N), phosphorus (P), calcium (Ca), sodium (Na), potassium (K), magnesium (Mg), exchangeable acidity (EA), percentage base saturation (\% BS), particle size, porosity, bulk density (BD), hydraulic conductivity (HC), and moisture content (MC) using standard methods. Direct ordination in canonical correspondence analysis was used to determine the influence of these soil factors on P. afra abundance, Shannon diversity, and species richness of both invaded and non-invaded sites. All sites differ from each other in terms of their physico-chemical parameters. The invaded sites appeared to be more acidic $(p H=3.22)$, less sandy, more porous (38.11\%), low HC (1.23) as compared with non-invaded ones. Soil factors that favoured abundance of P. afra (\% OM and EA) correlated negatively with Shannon diversity index of invaded sites which was positively influenced by $\% \mathrm{~N}, \mathrm{pH}$, and cation exchange capacity (CEC). At the non-invaded sites, Shannon index and density were influenced positively by $\% \mathrm{BS}, \mathrm{pH}, \mathrm{AP}$, and \% N. All these observations showed that the soil factors played significant roles in the establishment of $\mathrm{P}$. afra at the invaded sites, and also on the plant diversity at non-invaded sites.
\end{abstract}

Keywords: Invasive plants; Lafia; physico-chemical parameters; Pneumatopteris afra; wetlands

\section{ABSTRAK}

Hubungan antara faktor tanah dan ciri komuniti tanaman di sebilangan tanah lembap yang diserang dan yang tidak diserang oleh Pneumatopteris afra telah dikaji. Enam puluh sampel tanah diperoleh dari enam tanah lembap yang terdiri daripada tiga yang diserang dan tiga yang tidak diserang di Lafia, Nigeria menggunakan enam puluh kuadran yang disusun pada enam transek bersaiz $200 \mathrm{~m}$. Sampel yang telah dikering udara dan diayak menggunakan jaring 2 mm telah dianalisis untuk sifat fiziko-kimia yang meliputi $\mathrm{pH}$, bahan organik (OM), peratus nitrogen (\% N), fosforus $(P)$, kalsium (Ca), natrium (Na), kalium (K), magnesium (Mg), keasidan tertukarkan (EA), peratus ketepuan bes (\% $B S)$, ukuran zarah, keliangan, ketumpatan pukal (BD), kekonduksian hidraulik (HC) dan kandungan kelembapan (MC) menggunakan kaedah piawai. Pengordinatan langsung dalam analisis penghubungan berkanun digunakan untuk menentukan pengaruh faktor tanah terhadap kelimpahan P. afra, kepelbagaian Shannon dan kekayaan spesies daripada kedua-dua tapak yang diserang dan tidak diserang. Kesemua tapak adalah berbeza antara satu sama lain daripada segi parameter fiziko-kimia mereka. Tapak yang diserang kelihatan lebih berasid $(p H=3.22)$, kurang berpasir, lebih berpori (38.11\%), rendah HC (1.23) berbanding dengan tapak yang tidak diserang. Faktor tanah yang memihak kepada kelimpahan P. afra (\% OM dan EA) berkorelasi secara negatif dengan indeks kepelbagaian Shannon dari tapak yang diserang, dipengaruhi secara positif oleh \% N, pH dan keupayaan pertukaran kation (CEC). Pada tapak yang tidak diserang, indeks dan ketumpatan Shannon dipengaruhi secara positif oleh \% BS, pH, AP dan \% N. Semua pemerhatian ini menunjukkan bahawa faktor tanah memainkan peranan penting dalam penubuhan P. afra di lokasi yang diserang dan juga kepelbagaian tanaman di kawasan yang tidak diserang.

Kata kunci: Lafia; parameter fiziko-kimia; Pneumatopteris afra; tanah lembap; tumbuhan invasif 


\section{INTRODUCTION}

Plant invasion has been identified globally as one of the principal causes of native biodiversity loss and alterations of ecosystem structures and functions (Russell \& Blackburn 2017). The absence of natural enemies in new habitats, low plant diversity of resident communities, plant-fungi interactions, shift in climatic niches, rapid evolutionary process, and response to some abiotic factors including soil conditions are some of the predictors which explain the invasiveness of several plants in newly occupied geographical areas (Broennimann et al. 2007; Callaway et al. 2004; Klironomos 2002; Maron et al. 2004; Mitchell \& Power 2003; Richardson et al. 2000; Sabelis \& Crawley 1992; Wardle et al. 2011). Just like animals migrate during unfavourable climatic conditions in order to survive, plants also do the same by occupying new geographical territories of native plants, and this already threatened by climate change (Thomas et al. 2004). Such phenomenon results in new sets of invasive plants that are problematic to the environment.

The importance of soil to plants cannot be underrated as it forms the reservoir of nutrient elements, which are needed for metabolic activities in plants. Both major and minor elements necessary for plants growth and survival are domiciled in the soil (Landon 2014). Apart from dispersal of seeds, grazing, and other forms of land use, soil is an important factor that is responsible for the occurrence and distribution of plants in general (Laughlin \& Abella 2007; Normand et al. 2011; Ozinga et al. 2005; Ripple \& Beschta 2012). Changes in the nutrient contents of soil are known to influence the biomass accumulation of some plant species (Wang \& Chen 2019). These changes in soil biotic and abiotic properties are sometimes directly influenced by the invasive plants growing on the soil (Badalamenti et al. 2016; Gibbons et al. 2017). Researches have also shown that the invasive plants do require wide range of soil factors for their successful establishment, as compared to other species (Wamelink et al. 2014).

There were several reports on the roles of soil factor in plant species distributions in tropical and neotropical regions of the world (Khairil et al. 2011; Paoli et al. 2008). Soil $\mathrm{pH}$, organic matter content, cation exchange capacity, and nutrients were identified as the determinants of plants distributions in some tropical countries (Clark et al. 1999; Khairil et al. 2014). As climatic factors have been used to predict the invasiveness of many plants across the world, soil factors can also be harnessed to determine the invasive potential of plants as a part of risk assessment program (Lodge et al. 2006; Schulz et al. 2013). It is important to relate the status of a soil with the activities of invasive plants on the same soil in order to understand the mechanisms and impacts of invasion (Gioria \& Pyšek 2016). In this study, we investigated the relationship between soil physico-chemical parameters of some wetlands in Lafia, Nigeria (comprising those invaded by Pneumatopteris afra and non-invaded ones) and plant abundance, density, Shannon diversity index, and species richness.

Pneumatopteris afra (Christ.) Holttum is a tropical fern that has been reported to be a problematic colonizer of wetlands in some parts of North-Central Nigeria. This plant is also synonymously known as Cyclosorus afer (Christ.) Ching. There are lots of research gaps in the soil factors requirements of this fern at the invaded wetlands. Thus, it is very necessary to examine and compare the soil parameters of invaded and non-invaded wetlands with a view to isolate soil factors that mostly influence the plant abundance, diversity, and richness of those wetlands.

\section{MATERIALS AND METHODS}

\section{STUDY AREA}

The study was carried out in Lafia, Nasarawa State, Nigeria. Lafia is a city with guinea savannah vegetation comprising many woody shrubs, few trees, and grasses.

\section{COLLECTION OF SAMPLES}

Soil samples were collected from three wetlands invaded by $P$. afra and three wetlands that were not invaded by the plant (Figure 1). Soil samples were collected randomly at each wetland by digging the soil up to the level of underground rhizome/root of the plants (0 - 15 $\mathrm{cm})$ at the invaded and non-invaded sites using an auger. These soil samples were collected using ten $1.5 \times 1.5$ $\mathrm{m}^{2}$ quadrats laid at $10 \mathrm{~m}$ interval on one $200 \mathrm{~m}$ transect in each study site. This gives a total of 10 soil samples from each site and 60 samples from all study sites. The collected samples were properly labelled and air dried at room temperature in the laboratory for 3 days. Data for the species diversity, abundance, and richness of both invaded and non-invaded sites was obtained from our previous study (Akomolafe \& Rahmad 2020).

\section{DETERMINATION OF SOIL/SEDIMENT PHYSICAL AND CHEMICAL PARAMETERS}

Soil samples were sieved using $2 \mathrm{~mm}$ mesh. The physical parameters were determined using standard procedures. Soil $\mathrm{pH}$ was determined by glass electrode in a soil:water ratio of 1:2 (Chapman \& Pratt 1961). Mechanical method was used to obtain particle size distribution of the soil 


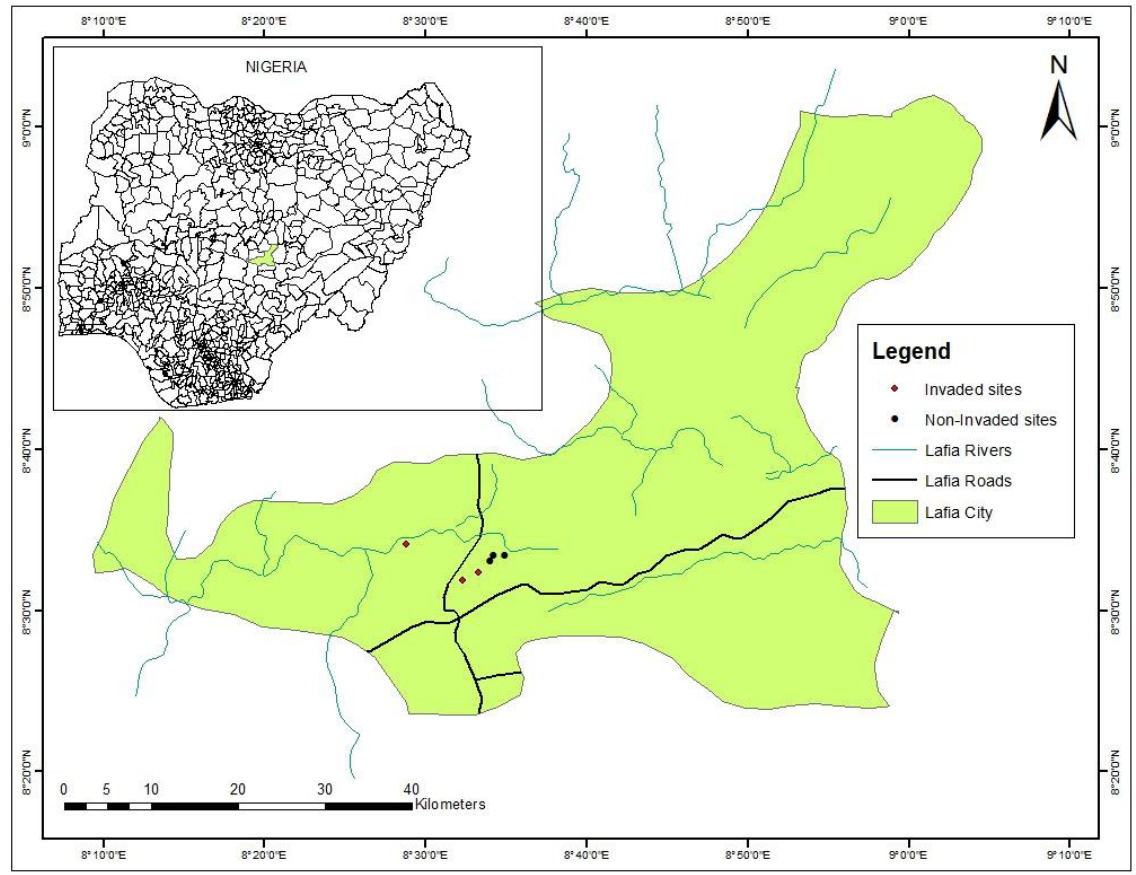

FIGURE 1. Map of Lafia, Nigeria, which was the study area (Akomolafe \& Rahmad 2020)

samples (Bouyoucos 1951). Also, soil texture, hydraulic conductivity (HC), moisture content (MC), bulk density (BD), and total porosity (TP) were determined (Ashman \& Puri 2013). As for the chemical properties of soil samples, following parameters were determined: percentage organic carbon (\% OC) and organic matter ( $\%$ OM) by wet acid digestion (Walkey \& Black 1934); percentage nitrogen $(\% \mathrm{~N})$ by Kjeldahl digestion method; available phosphorus (AP) (Olsen 1954); sodium (Na) and potassium $(\mathrm{K})$ by flame photometer; calcium $(\mathrm{Ca})$ and magnesium $(\mathrm{Mg})$ by atomic absorption spectrophotometer (AAS) (Rowell 2014); as well as exchangeable acidity (EA) and percentage base saturation (\% BS) by titration method (Pawluk \& Carson 1963). Cation exchange capacity (CEC) was obtained by adding the values of all cations together.

\section{STATISTICAL ANALYSES}

Canonical correspondence analysis (CCA) was carried out to determine the relationship between diversity indices, abundance of $P$. afra, and soil environmental factors at the invaded sites using PAST software 3.19 (Hammer et al. 2001). CCA was also carried out to determine the relationship between plant density, diversity indices, and soil environmental factors at the non-invaded sites. MonteCarlo Permutation test with 1000 bootstrap replicates was performed to determine the significance differences in the Eigen values of axes. One-way ANOVA with Duncan multiple range test was used to determine the significance differences in the means of each soil environmental factors between sites. This was achieved with 1000 bootstraps replicates using IBM SPSS 24.0.

\section{RESULTS AND DISCUSSION}

The success of some invasive plants has been linked with the activities of soil abiotic factors rather than the interactions with other plants (Czortek et al. 2020). In this study, the analysis of soil physical and chemical properties of invaded sites shows that there are variations among the sites (Table 1). These significant variations observed in the soil physical and chemical parameters among invaded and non-invaded sites showed the peculiarity of each site. Though they may look alike structurally and within the same geographical boundary, they still do not have the same physico-chemical properties which influence plant growth, survival, and diversity. There is no significant difference $(\mathrm{P}>0.05)$ in soil $\mathrm{pH}, \% \mathrm{~N}, \mathrm{AP}, \mathrm{EA}, \mathrm{CEC}, \% \mathrm{BS}$, $\%$ Sand, and \% Silt of the invaded sites. However, there are significant differences in the soil $\%$ OC, $\% \mathrm{O} \mathrm{M}, \%$ Clay, $\mathrm{HC}, \% \mathrm{MC}, \mathrm{BD}$, and $\% \mathrm{TP}$ of these invaded sites. Site 1 has the highest MC and TP of 85.83 and $41.33 \%$, respectively. TABLE 1 . Soil physical and chemical parameters of invaded 
sites

\begin{tabular}{lccc}
\hline Soil environmental factors & Site 1 & Site 2 & Site 3 \\
\hline $\mathrm{pH}\left(\mathrm{H}_{2} \mathrm{O}\right)$ & $2.43 \pm 0.08^{\mathrm{a}}$ & $4.24 \pm 1.08^{\mathrm{a}}$ & $2.99 \pm 0.08^{\mathrm{a}}$ \\
\% Organic carbon & $1.31 \pm 0.06^{\mathrm{bc}}$ & $1.12 \pm 0.01^{\mathrm{b}}$ & $1.60 \pm 0.18^{\mathrm{c}}$ \\
\% Organic matter & $2.24 \pm 0.09^{\mathrm{de}}$ & $1.92 \pm 0.02^{\mathrm{d}}$ & $2.75 \pm 0.31^{\mathrm{e}}$ \\
\% Nitrogen & $0.03 \pm 0.00^{\mathrm{f}}$ & $0.15 \pm 0.06^{\mathrm{f}}$ & $0.05 \pm 0.01^{\mathrm{f}}$ \\
Available phosphorus $(\mathrm{ppm})$ & $1.61 \pm 0.04^{\mathrm{g}}$ & $2.20 \pm 0.41^{\mathrm{g}}$ & $2.04 \pm 0.04^{\mathrm{g}}$ \\
Exchangeable acidity $(\mathrm{Cmol} / \mathrm{Kg})$ & $1.74 \pm 0.05^{\mathrm{h}}$ & $1.49 \pm 0.67^{\mathrm{h}}$ & $1.92 \pm 0.46^{\mathrm{h}}$ \\
Cation exchange capacity $(\mathrm{Cmol})$ & $3.51 \pm 0.06^{\mathrm{i}}$ & $5.00 \pm 0.83^{\mathrm{i}}$ & $4.12 \pm 0.26^{\mathrm{i}}$ \\
\% Base saturation & $50.13 \pm 0.59^{\mathrm{j}}$ & $62.43 \pm 2.46^{\mathrm{j}}$ & $70.78 \pm 4.11^{\mathrm{j}}$ \\
\% Sand & $81.03 \pm 3.14^{\mathrm{k}}$ & $88.40 \pm 0.40^{\mathrm{k}}$ & $81.43 \pm 3.73^{\mathrm{k}}$ \\
\% Silt & $4.07 \pm 0.67^{1}$ & $3.40 \pm 0.00^{\mathrm{l}}$ & $5.97 \pm 1.29^{1}$ \\
\% Clay & $14.67 \pm 2.57^{\mathrm{n}}$ & $7.83 \pm 0.03^{\mathrm{m}}$ & $11.77 \pm 1.98^{\mathrm{mn}}$ \\
Hydraulic conductivity $\left(\mathrm{cm}^{3}\right)$ & $1.59 \pm 0.00^{\mathrm{a}}$ & $1.04 \pm 0.00^{\mathrm{b}}$ & $1.06 \pm 0.01^{\mathrm{c}}$ \\
\% Moisture content & $85.83 \pm 0.17^{\circ}$ & $68.67 \pm 0.33^{\mathrm{p}}$ & $64.67 \pm 1.20^{\mathrm{q}}$ \\
Bulk density $\left(\mathrm{g} / \mathrm{cm}^{3}\right)$ & $1.56 \pm 0.00^{\mathrm{r}}$ & $1.77 \pm 0.00^{\mathrm{s}}$ & $1.71 \pm 0.01^{\mathrm{t}}$ \\
\% Total porosity & $41.33 \pm 0.33^{\mathrm{u}}$ & $38.33 \pm 0.33^{\mathrm{v}}$ & $34.67 \pm 0.33^{\mathrm{w}}$ \\
\hline
\end{tabular}

Values represent mean \pm Standard Error (SE). Means with the same superscripts across same rows are not significantly different $(\mathrm{P}>0.05)$ and vice versa

As for the non-invaded sites, there are significant differences in the soil parameters between the sites, except for $\%$ Silt, \% Clay, $\mathrm{HC}, \% \mathrm{MC}, \mathrm{BD}$, and \% TP where there are no significant differences (Table 2). Moreover, in comparison to the soil parameters between invaded and non-invaded sites, it was observed that there are no significant differences in their $\%$ OC, $\%$ OM, $\% \mathrm{~N}, \mathrm{EA}, \%$ BS, $\%$ Silt, \% Clay, and \% MC (Table 3). However, they only differ significantly in $\mathrm{pH}, \mathrm{AP}, \mathrm{CEC}, \%$ Sand, $\mathrm{HC}, \mathrm{BD}$, and \% TP. Non-invaded sites had higher $\mathrm{pH}, \mathrm{AP}, \mathrm{CEC}$, $\%$ Sand, HC, and BD than invaded sites which had the highest \% TP. It is worthy to note from our results that the non-invaded sites are less acidic and sandier than invaded ones. They also had less moisture content and porosity than invaded sites. This could imply that the sites invaded by P. afra are more physically suitable for its colonization due to their higher moisture content, acidity, and porosity.

TABLE 2. Soil physical and chemical parameters of non-invaded sites

\begin{tabular}{lccc}
\hline \multicolumn{1}{c}{ Soil environmental factors } & Site 1 & Site 2 & Site 3 \\
\hline $\mathrm{pH}\left(\mathrm{H}_{2} \mathrm{O}\right)$ & $3.23 \pm 0.01^{\mathrm{a}}$ & $5.61 \pm 0.01^{\mathrm{b}}$ & $4.45 \pm 0.01^{\mathrm{c}}$ \\
\% Organic carbon & $1.27 \pm 0.04^{\mathrm{d}}$ & $1.21 \pm 0.01^{\mathrm{d}}$ & $1.34 \pm 0.06^{\mathrm{d}}$ \\
\% Organic matter & $2.19 \pm 0.06^{\mathrm{ef}}$ & $2.09 \pm 0.02^{\mathrm{e}}$ & $2.32 \pm 0.06^{\mathrm{f}}$ \\
\% Nitrogen & $0.07 \pm 0.01^{\mathrm{f}}$ & $0.21 \pm 0.01^{\mathrm{g}}$ & $0.09 \pm 0.02^{\mathrm{f}}$ \\
Available phosphorus $(\mathrm{ppm})$ & $2.03 \pm 0.00^{\mathrm{h}}$ & $2.66 \pm 0.01^{\mathrm{i}}$ & $2.49 \pm 0.03^{\mathrm{j}}$ \\
Exchangeable acidity $(\mathrm{Cmol} / \mathrm{Kg})$ & $1.49 \pm 0.01^{1}$ & $1.12 \pm 0.06^{\mathrm{m}}$ & $1.34 \pm 0.01^{\mathrm{n}}$ \\
Cation exchange capacity $(\mathrm{Cmol})$ & $4.54 \pm 0.04^{\mathrm{o}}$ & $5.54 \pm 0.04^{\mathrm{p}}$ & $4.99 \pm 0.07^{\mathrm{q}}$ \\
\% Base saturation & $67.34 \pm 0.22^{\mathrm{r}}$ & $79.83 \pm 1.20^{\mathrm{s}}$ & $76.00 \pm 2.07^{\mathrm{s}}$ \\
\% Sand & $86.77 \pm 0.15^{\mathrm{t}}$ & $88.37 \pm 0.26^{\mathrm{u}}$ & $88.49 \pm 0.33^{\mathrm{u}}$ \\
\% Silt & $3.41 \pm 0.02^{\mathrm{v}}$ & $3.40 \pm 0.00^{\mathrm{v}}$ & $3.43 \pm 0.11^{\mathrm{v}}$ \\
\% Clay & $9.80 \pm 0.06^{\mathrm{w}}$ & $8.00 \pm 0.10^{\mathrm{w}}$ & $9.02 \pm 0.06^{\mathrm{w}}$ \\
Hydraulic conductivity $\left(\mathrm{cm}^{3}\right)$ & $24.25 \pm 0.05^{\mathrm{x}}$ & $24.25 \pm 0.03^{\mathrm{x}}$ & $24.22 \pm 0.22^{\mathrm{x}}$ \\
\% Moisture content & $68.00 \pm 0.58^{\mathrm{y}}$ & $68.00 \pm 0.00^{\mathrm{y}}$ & $68.46 \pm 0.31^{\mathrm{y}}$ \\
Bulk density $\left(\mathrm{g} / \mathrm{cm}^{3}\right)$ & $1.94 \pm 0.01^{\mathrm{z}}$ & $1.93 \pm 0.00^{\mathrm{z}}$ & $1.95 \pm 0.01^{\mathrm{z}}$ \\
\% Total porosity & $28.33 \pm 0.88^{\mathrm{a}}$ & $28.67 \pm 0.33^{\mathrm{a}}$ & $29.97 \pm 0.08^{\mathrm{a}}$ \\
\hline
\end{tabular}

Values represent mean \pm Standard Error (SE). Means with the same superscripts across same rows are not significantly different $(\mathrm{P}>0.05)$ and vice versa 
TABLE 3. Comparing the soil physical and chemical parameters of invaded and non-invaded sites

\begin{tabular}{ccc}
\hline Soil environmental factors & Invaded sites & Non-invaded sites \\
\hline pH $\left(\mathrm{H}_{2} \mathrm{O}\right)$ & $3.22 \pm 0.41^{\mathrm{a}}$ & $4.43 \pm 0.35^{\mathrm{b}}$ \\
\% Organic carbon & $1.34 \pm 0.09^{\mathrm{c}}$ & $1.28 \pm 0.03^{\mathrm{c}}$ \\
\% Organic matter & $2.30 \pm 0.15^{\mathrm{d}}$ & $2.19 \pm 0.04^{\mathrm{d}}$ \\
\% Nitrogen & $0.08 \pm 0.02^{\mathrm{e}}$ & $0.13 \pm 0.02^{\mathrm{e}}$ \\
Available phosphorus $(\mathrm{ppm})$ & $1.95 \pm 0.15^{\mathrm{f}}$ & $2.39 \pm 0.09^{\mathrm{g}}$ \\
Exchangeable acidity $(\mathrm{Cmol} / \mathrm{Kg})$ & $1.72 \pm 0.24^{\mathrm{h}}$ & $1.31 \pm 0.06^{\mathrm{h}}$ \\
Cation exchange capacity $(\mathrm{Cmol})$ & $4.21 \pm 0.33^{\mathrm{i}}$ & $5.02 \pm 0.15^{\mathrm{j}}$ \\
\% Base saturation & $61.11 \pm 1.50^{\mathrm{k}}$ & $74.39 \pm 1.97^{\mathrm{k}}$ \\
\% Sand & $83.62 \pm 1.85^{1}$ & $87.87 \pm 0.31^{\mathrm{m}}$ \\
\% Silt & $4.48 \pm 0.57^{\mathrm{n}}$ & $3.42 \pm 0.03^{\mathrm{n}}$ \\
\% Clay & $11.42 \pm 1.36^{\circ}$ & $8.94 \pm 0.26^{\circ}$ \\
Bulk density $\left(\mathrm{g} / \mathrm{cm}^{3}\right)$ & $1.23 \pm 0.09^{\mathrm{p}}$ & $24.23 \pm 0.06^{\mathrm{q}}$ \\
\% Total porosity & $73.06 \pm 3.26^{\mathrm{r}}$ & $68.15 \pm 0.20^{\mathrm{r}}$ \\
\hline Hydraulic conductivity $\left(\mathrm{cm}^{3}\right)$ & $1.68 \pm 0.03^{\mathrm{s}}$ & $1.94 \pm 0.01^{\mathrm{t}}$ \\
\hline
\end{tabular}

Values represent mean \pm Standard Error (SE). Means with the same superscripts across same rows are not significantly different $(\mathrm{P}>0.05)$ and vice versa

In terms of nutrient composition of both invaded and non-invaded sites, there seems not to be any contradiction because both sites are similar. Hydraulic conductivity (HC) has been known to be closely related with texture, organic matter, and bulk density of soils in such a way that it increases with increasing pore spaces (macropores) of the soils (Vereecken 1995; Wösten \& Van Genuchten 1988). These macropores are either created by soil organisms (faunas) or roots of some specific plants such as legumes (Beven \& Germann 2013; Edwards et al. 1990). However, massive growth of some plant roots normally closes the macropores and thereby decreases hydraulic conductivity of soils (Bodner et al. 2008). This might be the cause for very low amount of $\mathrm{HC}$ reported at invaded sites as compared to the non-invaded sites where there was no massive growth of plants. Other studies reported that soils with mixture of grasses and legumes tend to have high $\mathrm{HC}$ due to the enhancement of macropores by their roots which also promote organic matter content and abundant earthworms (Fischer et al. 2014; Obi 1999). Therefore, high $\mathrm{HC}$ observed at the non-invaded sites might have been favored by the mixture of grasses, legumes, and other plants there. Also, a negative correlation was established between soil coarseness and $\mathrm{HC}$ due to the poorly formed soil structure and low macroporosity, except for soils with high composition of legumes (Jarvis \& Messing 1995; Lin et al. 1999; Six et al. 2004). It is expected that the non-invaded sites with higher proportion of sands (coarseness) will have low infiltration capacity. However, contradictory finding was observed for the non-invaded sites, which have higher $\mathrm{HC}$ despite the coarseness nature.

The sandy nature of soils at invaded sites coupled with the rhizomatous nature of roots of $P$. afra which dominated there, could have led to the reduction of macropores and population of earthworm in soils, thereby resulting in very low HC (Archer et al. 2002; Bens et al. 2007; Kördel et al. 2008). Furthermore, soils that are more biologically active have been closely associated with high organic carbon, high organic matter, low bulk density, and high porosity (Pérès et al. 2013; Zacharias \& Wessolek 2007). Such soils are regarded as having more stable aggregates. Therefore, the soils of invaded sites can be inferred to be more stable and biologically active than the non-invaded. In agreement with this work, Sharma et al. (2017) also observed that soils invaded by Hyptis suaveolens in India were more acidic, with a higher \% OC and $\%$ OM than the non-invaded. High $\%$ OC and \% OM observed at the invaded sites could be attributed to high biomass of $P$. afra at the sites, which usually promotes high soil organic carbon and matter (Koutika et al. 2007; Liao et al. 2009).

Twelve soil environmental factors were used for the Canonical Correspondence Analysis (CCA). The results of CCA established the relationship between these soil factors and plant community characteristics of both invaded and non-invaded wetlands studied (Khairil et al. 
2014). Eigen value has been known to be an important parameter representing the strength and degree of variation along an axis (Khairil et al. 2015). The Eigen values, percentage variation, and significant values of axes are shown in Table 4. Axes 1 and 2 for invaded sites have 86.69 and $13.31 \%$ strength, respectively. Those of non-invaded sites include $89.02 \%$ for axis 1 and $10.98 \%$ for axis 2 . The permutation test showed no significant difference in the Eigen values of three ordination axes of both invaded and non-invaded sites $(P>0.05)$. This showed that the degree of variation of axis 1 is higher than axis 2 for both invaded and non-invaded sites. This is also an indication that soil physico-chemical parameters examined had much influence on the plant community characteristics (abundance, richness, density, and diversity index) of both invaded and non-invaded sites.

TABLE 4. The relationship between the study sites and soil factors

\begin{tabular}{|c|c|c|c|c|}
\hline & \multicolumn{2}{|c|}{ Invaded sites } & \multicolumn{2}{|c|}{ Non-invaded sites } \\
\hline & Axis 1 & Axis 2 & Axis 1 & Axis 2 \\
\hline Eigen value & 0.8669 & 0.1331 & 0.8902 & 0.1098 \\
\hline$\%$ Variation & 86.69 & 13.31 & 89.02 & 10.98 \\
\hline P-value & 0.48 & 0.65 & 0.68 & 0.66 \\
\hline
\end{tabular}

The CCA result shows the relationship between the Shannon diversity, species richness, abundance of $P$. afra, and environmental variables (soil parameters) at the invaded sites (Figure 2). Hydraulic conductivity (HC), \% MC, and \% TP were the factors that influenced species richness at the invaded sites. Percentage organic matter (\%OM) and EA correlated positively with the abundance of $P$. afra. Meanwhile AP, $\% \mathrm{~N}, \mathrm{pH}$, and CEC correlated negatively with it. Shannon diversity was influenced by the $\% \mathrm{~N}, \mathrm{pH}, \mathrm{CEC}$, and AP which correlated negatively with the abundance of $P$. afra at the invaded sites.

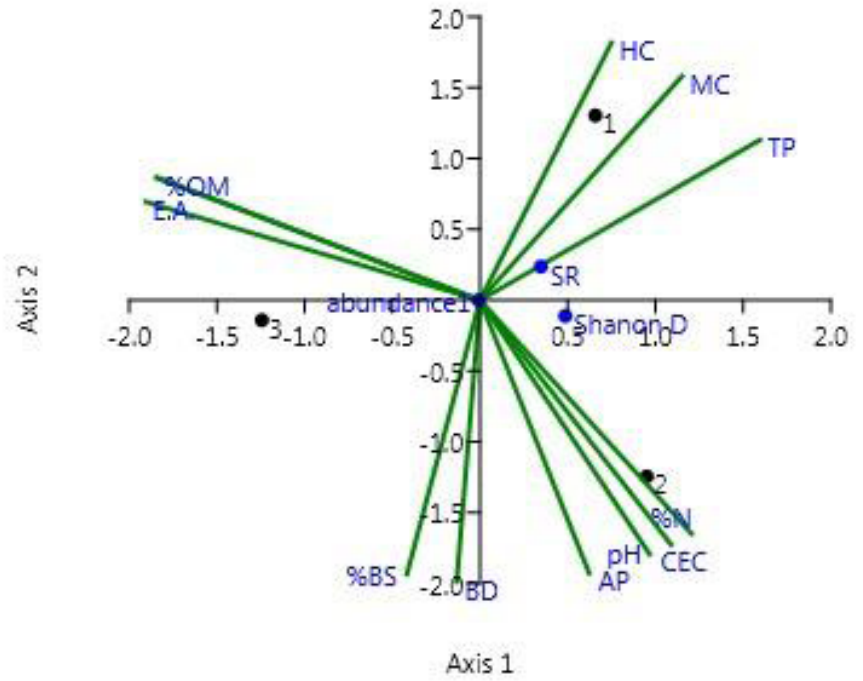

FIGURE 2. Canonical Correspondence Analysis (CCA) biplot showing the relationship between abundance of $P$. afra, Shannon diversity, species richness, and soil environmental variables of the invaded sites in Lafia, Nigeria 
At these invaded sites, the factors that influenced Shannon diversity index (i.e. AP, $\% \mathrm{~N}, \mathrm{pH}$, and CEC) also affected the abundance of $P$. afra negatively. This is so significant because it has been reported in our previous study that the colonization of $P$. afra has negative impact on the plant diversity of resident wetland communities. This means that, the higher the AP, $\% \mathrm{~N}, \mathrm{pH}$, and CEC, the lower the abundance of $P$. afra. As for the non-invaded sites, species richness was influenced positively by EA, $\%$ OC, and \% OM (Figure 3). Shannon diversity index and density were influenced positively by $\% \mathrm{BS}, \mathrm{pH}$, AP, and $\%$ N. All these diversity indices of the non-invaded sites were negatively influenced by $\mathrm{HC}, \% \mathrm{MC}, \mathrm{BD}, \% \mathrm{TP}$, and CEC.

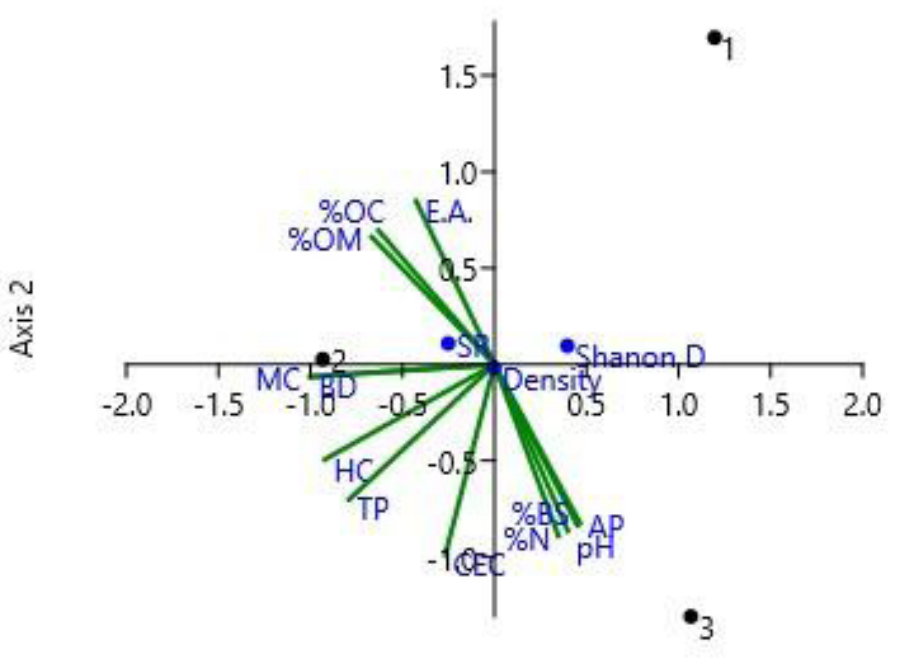

Axis 1

FIGURE 3. Canonical Correspondence Analysis (CCA) biplot showing the relationship between plant density, Shannon diversity index, species richness, and soil environmental variables of the non-invaded sites in Lafia, Nigeria

Thus, it can be deduced that $P$. afra prefers to thrive well in more acidic, less phosphorus, and nutrient-poor soils. This more-acidic (low $\mathrm{pH}$ ) nature of invaded sites could have been directly caused by the activities of $P$. afra. This is supported by the report that invasive plants directly or indirectly alter the acidification of soil through the release of some secondary metabolites as root exudates to promote their competitive advantage over other plants (Weidenhamer \& Callaway 2010). A positive correlation has been established between the invasion of Wedelia trilobata through allelopathy and soil acidity in South China (Wang et al. 2012). Also, the invasion of Solidago gigantea increased the soil acidity of invaded grassland communities (Teixeira et al. 2020). Another invasive fern Lygodium microphyllum is known to be associated with increased soil acidity in its native range than the invaded range (Soti et al. 2020). However, these studies contradict the report on the invasion of another plant (Acacia dealbata) which increased the alkalinity of soil where it invaded in Northwest Spain (Lorenzo et al. 2010). Hence, the activity of invasive plants on the soil acidification is dependent on the type of plant. As for $P$. afra, one of the ways to limit its invasive success could be through the addition of lime to the wetlands because lime tends to reduce soil acidity (Athanase et al. 2013). A recent research on the influence of nitrogen on the competitive performance of an invader Aegilops tauschii showed that this plant was able to thrive well and grew abundantly over other plants in a condition of high nitrogen stress in China (Wang \& Chen 2019). However, this contradicts our result which showed that $P$. afra prefers nitrogenpoor environment. These same soil factors $(\% \mathrm{~N}, \mathrm{pH}$, and 
AP) still affected the diversity index of non-invaded sites positively. It should also be noted that the non-invaded sites are more basic. This explains why the plant diversity index is influenced by the amount of basic ions (\% BS) in the sites.

Soil $\mathrm{pH}$, salinity, and nutrient have also been reported to have much influence on the distribution of some other invasive plants across tropical and temperate regions of the world (Flowers \& Colmer 2008; Galatowitsch et al. 1999; Wamelink et al. 2018). Unlike P. afra which was not positively influenced by increased nitrogen in the soils, some other invasive plants have very strong positive correlation with increased nitrogen in the soil (Thuiller et al. 2005; Wamelink et al. 2014). Therefore, the invasion of $P$. afra in these wetlands strongly disagrees with the hypothesis that increased deposition of nitrogen in the environment will influence the threats of plant invasion (Galloway et al. 2004). This simply denotes that the wetlands invaded by $P$. afra in Lafia, Nigeria are less polluted with nitrogenous compounds, hence lower amount of nitrogen found in the soils. As suggested by the European Union on management of invasive plants, early reports on soil abiotic requirements of potential invasive plants should be utilized rapidly in combating the future menace of invasion (Wamelink et al. 2018).

\section{CONCLUSION}

This study has provided an early report on soil abiotic preferences of $P$. afra in some wetlands in Nigeria. This could also serve as early warning for its future spread if not properly managed. It showed that the soil physicochemical parameters had very much effect on the abundance of $P$. afra, Shannon diversity index, and species richness at the invaded wetlands. They also have similar influence on plant diversity and richness of non-invaded wetlands. Although two categories of sites have similar structure and geographic boundary, they still differ in their preferences for soil parameters as shown by the results of physico-chemical analyses and CCA. The preferred soil parameters that favored the colonization of $P$. afra at invaded sites were found to have low $\mathrm{pH}$, low $\mathrm{HC}$, low \% $\mathrm{N}$, high EA, and OM. Therefore $P$. afra can be regarded as an invasive species with a wide range of soil factors. The prevention of further spread of this plant may be ensured by reducing the acidification and increasing nitrogen contents of the wetlands.

\section{ACKNOWLEDGEMENTS}

We acknowledge the Nigerian Government Tertiary Education Trust Fund (TETFund) ASTD PhD Grant (FUL/ REG/TETfund/002/VOL.II/182) and USM Research University Grant (RU) (1001/PBIOLOGI/811300) for financially supporting this study.

\section{REFERENCES}

Akomolafe, G.F. \& Rahmad, Z.B. 2020. Wetlands invaded by Pneumatopteris afra (Christ.) Holttum are more threatened than non-invaded ones in Nigeria. Songklanakarin Journal of Science and Technology 42(4): 858-864.

Archer, N.A.L., Quinton, J.N. \& Hess, T.M. 2002. Below-ground relationships of soil texture, roots and hydraulic conductivity in two-phase mosaic vegetation in South-east Spain. Journal of Arid Environments 52(4): 535-553.

Ashman, M. \& Puri, G. 2013. Essential Soil Science: A Clear and Concise Introduction to Soil Science. New York: John Wiley \& Sons.

Athanase, N., Vicky, R., Jayne, M.N. \& Sylvestre, H. 2013. Soil acidification and lime quality: Sources of soil acidity, its effects on plant nutrients, efficiency of lime and liming requirements. Agricultural Advances 2(9): 259-269.

Badalamenti, E., Gristina, L., Laudicina, V.A., Novara, A., Pasta, S. \& La Mantia, T. 2016. The impact of Carpobrotus cfr. acinaciformis (L.) L. Bolus on soil nutrients, microbial communities structure and native plant communities in Mediterranean ecosystems. Plant and Soil 409(1-2): 19-34.

Bens, O., Wahl, N.A., Fischer, H. \& Hüttl, R.F. 2007. Water infiltration and hydraulic conductivity in sandy cambisols: Impacts of forest transformation on soil hydrological properties. European Journal of Forest Research 126(1): 101-109.

Beven, K. \& Germann, P. 2013. Macropores and water flow in soils revisited. Water Resources Research 49(6): 30713092.

Bodner, G., Loiskandl, W., Buchan, G. \& Kaul, H.P. 2008. Natural and management-induced dynamics of hydraulic conductivity along a cover-cropped field slope. Geoderma 146(1-2): 317-325.

Bouyoucos, G.J. 1951. A recalibration of the hydrometer method for making mechanical analysis of soils. Agronomy Journal 43(9): 434-438.

Broennimann, O., Treier, U.A., Müller-Schärer, H., Thuiller, W., Peterson, A.T. \& Guisan, A. 2007. Evidence of climatic niche shift during biological invasion. Ecology Letters 10(8): 701-709.

Callaway, R.M., Thelen, G.C., Rodriguez, A. \& Holben, W.E. 2004. Soil biota and exotic plant invasion. Nature 427(6976): 731.

Chapman, H.D. \& Pratt, P.F. 1961. Methods of analysis for soils. Plants and Waters: 169-176.

Clark, D.B., Palmer, M.W. \& Clark, D.A. 1999. Edaphic factors and the landscape-scale distributions of tropical rain forest trees. Ecology 80(8): 2662-2675.

Czortek, P., Królak, E., Borkowska, L. \& Bielecka, A. 2020. Impacts of soil properties and functional diversity on the performance of invasive plant species Solidago canadensis L. on post-agricultural wastelands. Science of The Total Environment 729: 139077.

Edwards, W.M., Shipitalo, M.J., Owens, L.B. \& Norton, L.D. 1990. Effect of Lumbricus terrestris L. burrows on hydrology of continuous no-till corn fields. Geoderma 46(1-3): 73-84. 
Fischer, C., Roscher, C., Jensen, B., Eisenhauer, N., Baade, J., Attinger, S., Scheu, S., Weisser, W.W., Schumacher, J. \& Hildebrandt, A. 2014. How do earthworms, soil texture and plant composition affect infiltration along an experimental plant diversity gradient in grassland? PLOS ONE 9(6): e98987.

Flowers, T.J. \& Colmer, T.D. 2008. Salinity tolerance in halophytes. New Phytologist 179(4): 945-963.

Galatowitsch, S.M., Anderson, N.O. \& Ascher, P.D. 1999. Invasiveness in wetland plants in temperate North America. Wetlands 19(4): 733-755.

Galloway, J.N., Dentener, F.J., Capone, D.G., Boyer, E.W., Howarth, R.W., Seitzinger, S.P., Asner, G.P., Cleveland, C.C., Green, P.A. \& Holland, E.A. 2004. Nitrogen cycles: Past, present, and future. Biogeochemistry 70(2): 153-226.

Gioria, M. \& Pyšek, P. 2016. The legacy of plant invasions: Changes in the soil seed bank of invaded plant communities. BioScience 66(1): 40-53.

Gibbons, S.M., Lekberg, Y., Mummey, D.L., Sangwan, N., Ramsey, P.W. \& Gilbert, J.A. 2017. Invasive plants rapidly reshape soil properties in a grassland ecosystem. MSystems 2(2): e00178-16.

Hammer, Ø., Harper, D.A.T. \& Ryan, P.D. 2001. PAST: Paleontological statistics software package for education and data analysis. Palaeontologia Electronica 4(1): 1-9.

Jarvis, N.J. \& Messing, I. 1995. Near-saturated hydraulic conductivity in soils of contrasting texture measured by tension infiltrometers. Soil Science Society of America Journal 59(1): 27-34.

Khairil, M., Siti-Meriam, A., Nur-Fatihah, H.N., Nashriyah, M., Razali, M.S. \& Noor-Amalina, R. 2015. Association of edaphic factors with herbal plants abundance and density in a recreational forest, Terengganu, Peninsular Malaysia. Malaysia Applied Biology 44(2): 33-43.

Khairil, M., Juliana, W.A.W. \& Nizam, M.S. 2014. Edaphic influences on tree species composition and community structure in a tropical watershed forest in peninsular Malaysia. Journal of Tropical Forest Science 26(2): 284294.

Khairil, M., Juliana, W.A.W., Nizam, M.S. \& Faszly, R. 2011. Community structure and biomass of tree species at Chini watershed forest, Pekan, Pahang. Sains Malaysiana 40(11): 1209-1221.

Klironomos, J.N. 2002. Feedback with soil biota contributes to plant rarity and invasiveness in communities. Nature 417(6884): 67-70

Kördel, W., Egli, H. \& Klein, M. 2008. Transport of pesticides via macropores (IUPAC technical report). Pure and Applied Chemistry 80(1): 105-160.

Koutika, L., Vanderhoeven, S., Chapuis-Lardy, L., Dassonville, N. \& Meerts, P. 2007. Assessment of changes in soil organic matter after invasion by exotic plant species. Biology and Fertility of Soils 44(2): 331-341.

Landon, J.R. 2014. Booker Tropical Soil Manual: A Handbook for Soil Survey and Agricultural Land Evaluation in the Tropics and Subtropics. London: Routledge.

Laughlin, D.C. \& Abella, S.R. 2007. Abiotic and biotic factors explain independent gradients of plant community composition in ponderosa pine forests. Ecological Modelling 205(1-2): 231-240.

Liao, Q., Zhang, X., Li, Z., Pan, G., Smith, P., Jin, Y. \& Wu, X. 2009. Increase in soil organic carbon stock over the last two decades in China's Jiangsu Province. Global Change Biology 15(4): 861-875.

Lin, H.S., McInnes, K.J., Wilding, L.P. \& Hallmark, C.T. 1999. Effects of soil morphology on hydraulic properties I. Quantification of soil morphology. Soil Science Society of America Journal 63(4): 948-954.

Lodge, D.M., Williams, S., MacIsaac, H.J., Hayes, K.R., Leung, B., Reichard, S., Mack, R.N., Moyle, P.B., Smith, M. \& Andow, D.A. 2006. Biological invasions: Recommendations for US policy and management. Ecological Applications 16(6): 2035-2054.

Lorenzo, P., Rodríguez-Echeverría, S., González, L. \& Freitas, H. 2010. Effect of invasive Acacia dealbata link on soil microorganisms as determined by PCR-DGGE. Applied Soil Ecology 44(3): 245-251.

Maron, J.L., Vilà, M., Bommarco, R., Elmendorf, S. \& Beardsley, P. 2004. Rapid evolution of an invasive plant. Ecological Monographs 74(2): 261-280.

Mitchell, C.E. \& Power, A.G. 2003. Release of invasive plants from fungal and viral pathogens. Nature 421(6923): 625627.

Normand, S., Ricklefs, R.E., Skov, F., Bladt, J., Tackenberg, O. \& Svenning, J. 2011. Postglacial migration supplements climate in determining plant species ranges in Europe. Proceedings of the Royal Society B: Biological Sciences 278(1725): 3644-3653.

Obi, M.E. 1999. The physical and chemical responses of a degraded sandy clay loam soil to cover crops in southern Nigeria. Plant and Soil 211(2): 165-172.

Olsen, S.R. 1954. Estimation of Available Phosphorus in Soils by Extraction with Sodium Bicarbonate. US Department of Agriculture.

Ozinga, W.A., Joop, H.J., Schaminée, R.M., Bekker, S.B., Peter, P., Oliver, T., Jan, B. \& Jan, M.G. 2005. Predictability of plant species composition from environmental conditions is constrained by dispersal limitation. Oikos 108(3): 555-561.

Paoli, G.D., Curran, L.M. \& Slik, J.W.F. 2008. Soil nutrients affect spatial patterns of aboveground biomass and emergent tree density in southwestern Borneo. Oecologia 155(2): 287-299.

Pawluk, S. \& Carson, J.A. 1963. Evaluation of methods for determination of exchange acidity in soils. Canadian Journal of Soil Science 43(2): 325-335.

Pérès, G., Cluzeau, D., Menasseri, S., Soussana, J., Bessler, H., Engels, C., Habekost, M., Gleixner, G., Weigelt, A. \& Weisser, W.W. 2013. Mechanisms linking plant community properties to soil aggregate stability in an experimental grassland plant diversity gradient. Plant and Soil 373(1-2): 285-299.

Richardson, D.M., Allsopp, N., D’Antonio, C.M., Milton, S.J. \& Rejmánek, M. 2000. Plant invasions-the role of mutualisms. Biological Reviews 75(1): 65-93. 
Ripple, W.J. \& Beschta, R.L. 2012. Trophic cascades in Yellowstone: The first 15 years after wolf reintroduction. Biological Conservation 145(1): 205-213.

Rowell, D.L. 2014. Soil Science: Methods \& Applications. London: Routledge.

Russell, J.C. \& Blackburn, T.M. 2017. The rise of invasive species denialism. Trends in Ecology and Evolution 32: 3-6.

Sabelis, M.W. \& Crawley, M.J. 1992. Natural Enemies: The Population Biology of Predators, Parasites and Diseases. New York: John Wiley \& Sons.

Schulz, M., Gauss, M., Benedictow, A., Jonson, J.E., Tsyro, S., Nyıri, A., Simpson, D., Steensen, B.M., Klein, H. \& Valdebenito, A. 2013. EMEP Status Report 2011. Transboundary Acidification, Eutrophication and Ground Level Ozone in Europe in 2011. Norway: Norwegian Meteorology Institute.

Sharma, A., Batish, D.R., Singh, H.P., Jaryan, V. \& Kohli, R.K. 2017. The impact of invasive Hyptis suaveolens on the floristic composition of the periurban ecosystems of Chandigarh, northwestern India. Flora 233: 156-162.

Six, J., Bossuyt, H., Degryze, S. \& Denef, K. 2004. A history of research on the link between (micro) aggregates, soil biota, and soil organic matter dynamics. Soil and Tillage Research 79(1): 7-31.

Soti, P.G., Purcell, M. \& Jayachandran, K. 2020. Soil biotic and abiotic conditions negate invasive species performance in native habitat. Ecological Processes 9(1): 1-9.

Teixeira, L.H., Yannelli, F.A., Ganade, G. \& Kollmann, J. 2020 Functional diversity and invasive species influence soil fertility in experimental grasslands. Plants 9(1): 53.

Thomas, C.D., Cameron, A., Green, R.E., Bakkenes, M., Beaumont, L.J., Collingham, Y.C., Erasmus, B.F.N., De Siqueira, M.F., Grainger, A. \& Hannah, L. 2004. Extinction risk from climate change. Nature 427(6970): 145-148.

Thuiller, W., Richardson, D.M., Pyšek, P., Midgley, G.F., Hughes, G.O. \& Rouget, M. 2005. Niche-based modelling as a tool for predicting the risk of alien plant invasions at a global scale. Global Change Biology 11(12): 2234-2250.

Vereecken, H. 1995. Estimating the unsaturated hydraulic conductivity from theoretical models using simple soil properties. Geoderma 65(1-2): 81-92.

Walkey, A. \& Black, I.A. 1934. An examination of Degtjareff method for determination of soil organic matter and a proposed modification of the chromic acid in soil analysis. Experimental Journal of Soil Science 79: 459-465.

Wamelink, W., van Dobben, H.F., Goedhart, P.W. \& JonesWalters, L.M. 2018. The role of abiotic soil parameters as a factor in the success of invasive plant species. Emerging Science Journal 2(6): 308-365.
Wamelink, G.W.W., Goedhart, P.W. \& Frissel, J.Y. 2014. Why some plant species are rare? PLOS ONE 9(7): e102674.

Wang, N. \& Chen, H. 2019. Increased nitrogen deposition increased the competitive effects of the invasive plant Aegilops tauschii on wheat. Acta Physiologiae Plantarum 41(10): 176.

Wang, R.L., Staehelin, C., Dayan, F.E., Song, Y.Y., Su, Y.J. \& Zeng, R.S. 2012. Simulated acid rain accelerates litter decomposition and enhances the allelopathic potential of the invasive plant Wedelia trilobata (creeping daisy). Weed Science 60(3): 462-467.

Wardle, D.A., Bardgett, R.D., Callaway, R.M. \& Van der Putten, W.H. 2011. Terrestrial ecosystem responses to species gains and losses. Science 332(6035): 1273-1277.

Weidenhamer, J.D. \& Callaway, R.M. 2010. Direct and indirect effects of invasive plants on soil chemistry and ecosystem function. Journal of Chemical Ecology 36(1): 59-69.

Wösten, J.H.M. \& Van Genuchten, M.T. 1988. Using texture and other soil properties to predict the unsaturated soil hydraulic functions. Soil Science Society of America Journal 52(6): 1762-1770

Zacharias, S. \& Wessolek, G. 2007. Excluding organic matter content from pedotransfer predictors of soil water retention. Soil Science Society of America Journal 71(1): 43-50.

Akomolafe Gbenga Festus* \& Rahmad Zakaria

School of Biological Sciences

Universiti Sains Malaysia

11800 Gelugor, Pulau Pinang

Malaysia

Akomolafe Gbenga Festus*

Department of Botany

Federal University of Lafia

PMB 146, Lafia

Nigeria

Rahmad Zakaria

Center for Global Sustainability Studies (CGSS)

Level 5, Hamzah Sendut Library 1

Universiti Sains Malaysia

11800 Gelugor, Pulau Pinang

Malaysia

*Corresponding author; email: gfakomolafe@yahoo.com

Received: 17 February 2020

Accepted: 22 July 2020 